\title{
Solar Village in Malaysia - A Route Map for Financing Mechanism
}

\author{
Nur Azfahani Ahmad ${ }^{1, a}$, Hugh Byrd ${ }^{2}$, Nurul Fadzila Zahari ${ }^{1}$, Suriani Ngah Abdul Wahab ${ }^{1}$, Aida Affina Abdul Ghani ${ }^{1}$ \\ ${ }^{1}$ Faculty of Architecture, Planning and Surveying, UiTM Perak, 32610, Perak, Malaysia \\ 2 School of Architecture, University of Lincoln, Brayford Pool, LN6 7TS, United Kingdom
}

\begin{abstract}
Malaysia's development has been largely financed from its fossil fuels resources that come principally from the South China Sea. This has enabled electricity to be distributed equitably throughout society and improved the quality of life for people in Malaysia. However, the depletion of fossil fuel resources and the international conflict over South China Sea territorial ownership may leads to inadequacy of supply in the future, and may give direct impact to people in the rural areas. Malaysia's greatest potential for solar energy comes from photovoltaics (PVs) and the large roofs of village houses offer significant potential to contribute electricity both nationally and to the local communities. However, this technology is still unfamiliar to the people living in local villages due to the subsidised electricity by TNB and high capital costs of PV systems. This paper investigates whether establishing a "solar village" is feasible in Malaysia. Through a cost feasibility analysis, the potential of harnessing solar electricity for local villages in Malaysia has been demonstrated. A novel mechanism has been presented that allows rural households to own PV panels, rent the grid cables and to share surplus electricity within the community through a three (3) way financing routes map.
\end{abstract}

\section{Introduction}

As 2011 ends, Malaysia ${ }^{a}$ has recorded an annual GDP growth of $5.6 \%$ (The World Bank, 2013) and an increasing rate of residential areas for both urban and rural areas by $20 \%$ (Department of Statistic Malaysia, 2011). This situation has influenced the rapid market for electrical appliances ownerships (Saidur, Masjuki, \& Jamaluddin, 2007) which contributed towards the increased demand of electricity. It is projected that, in the next decade, electricity generation is expected to increase more than $40 \%$ of global energy consumption (EIA, 2013). Rural areas in Malaysia with the population of almost half the nation population have recorded $93 \%$ of electricity coverage (TNB, 2009), marking a good record of electricity supply for Malaysia, compared to other Asian countries. APEC (2013) projected that the electricity generation in Malaysia will continue to grow at an average rate of $2.8 \%$ every year. The generation is projected to grow from 105.1 TWh in 2009 to $217 \mathrm{TWh}$ in 2035 (APEC, 2013).

However, as development continue to rise and people keep on consuming electricity, it has rise many associated issues. Among the issue is how Malaysia can fulfil the growing demands for energy over the future. With its economic growth and increasing population, this will lead

${ }^{\text {a }}$ It has been estimated that, by 2030 , the population in Malaysia will have increased to 37 million people and that this will also affect the rate of GDP by up to USD850 billion per capita (APEC, 2006).

\footnotetext{
${ }^{\mathrm{a}}$ Corresponding author: nuraz020@perak.uitm.edu.my
}

to a substantial increase in electricity demand. With the depletion issues of fossil fuels (Nel \& Cooper, 2009) and increased costs of fuels for electricity generation (Fantazzini, Höök, \& Angelantoni, 2011), Malaysian Government is now gradually reducing the subsidy (Gardner-Stephens, 2013; Hamid \& Rashid, 2012). It is projected that, in the future, electricity cost will be expensive (Shagar, 2013) and people live in rural areas will experience a tough life due to this situation (Ahmad $\&$ Byrd, 2012). The rising cost of electricity could result in poverty. This is supported by Pellegrini and Tasciotti (2012) who have implied that the cost of electricity distribution to the low population densities results in a high cost for each unit of electricity consumed. Therefore, it is necessary to consider and project future trends of electricity consumption in Malaysia, in order to expect a suitable share of electricity for the people in the future. Fundamentally, in order to cater this issue, renewable energy resources need to be taken into the account..

\section{Future Issue of Rural Electrification in Malaysia}

Barnes (2005) has highlighted that the poverty line in rural areas has declined in many developing countries due to the effective in electricity coverage for these areas. This has been proven in Malaysia where with the effective rural electrification programme by the Government and Tenaga Nasional Berhad (Ab Kadir, 
Rafeeu, \& Adam, 2010), it has reduce the income disparities between rural and urban people, increase the quality of life and improve the education processes. Electricity has empowered rural businesses, help to operate farm machineries, lighting households, street lighting and public buildings. This has created electricitydepended lifestyles among rural people in Malaysia.

However, since electricity generation in Malaysia is dependent to oil and gas, fluctuation in fuel prices will give a direct impact to the power cost. This is argued by a Malaysian energy observer organisation, MyPower Corporation (2013), which indicated that the actual cost of electricity would spike to MYR 40 cent/kwh if the fuel subsidies are to be removed in the year 2016. A complete dependence on fuel resources to generate electricity exposes people to variation in price and unreliable service which leads to uncertainties of electricity supply (IEA, 2013). These uncertainties may lead to other associated problem, like poverty and energy security issues. Since rural people in Malaysia are fully reliant on centralised electricity provided by the Government, any concurrent issues of electricity supply will give them full impact especially if the issue of subsidy removal reaches the national level. With household income of MYR 750.00 per month and below (PEMANDU, 2011), many rural people do not have the capacity or means to establish basic necessities other than relying to electricity provided by the Government. Thus, it is necessary for the Government to consider a strategic plan on establishing alternative energy resources for these people, in facing any energy issues in the future.

\section{Solar Village : The Potential}

The potential of utilizing solar energy for generating electricity through photovoltaic (PV) panels on Malaysian homes is substantial, with an average solar irradiance per year of $1643 \mathrm{kWh} / \mathrm{m} 2$ (Chua, Oh, \& Goh, 2011). Many scholars have identified that solar energy power which comes from PV panels could readily meet up to $20 \%$ of Malaysia's energy needs (Chua et al., 2011; Muhammad-Sukki, Ramirez-Iniguez, Abu-Bakar, McMeekin, \& Stewart, 2011).

Developing countries like China, India, Nepal and Bangladesh have already implemented plans to generate solar-powered electricity for rural dwellers. Solar electrification in these countries helps to create business opportunities for local people and provide an independent practice that can help rural dwellers to own PV panels (Barnes \& Foley, 2004; Chaurey \& Kandpal, 2009; Islam \& Islam, 2005; Subhes, 2006).

In the case of Malaysia, the success of the $5^{\text {th }}$ Fuel Diversification Strategy energy policy in the 9th Malaysia Plan (2006-2010) (Malaysia, 2006), has introduced the integrated solar panel technology to residential and industrial sectors (Mekhilef et al., 2011; F. Muhammad-Sukki et al., 2011). However, it only reached extensively to the urban area. This technology is still unfamiliar to the rural people (Haw, Sopian, Sulaiman, Hafidz, \& Yahya, 2009). Jamaludin (2009) highlighted that even though solar energy has great potential in
Malaysia and becomes known to the people in urban area, the capital cost for implementing this technology is still considered high for rural people.

The potential for utilizing solar electricity in rural Malaysia is high. Byrd (2010) has argued that rural houses in Malaysia; if installed with solar panels, could generate and meet about $25 \%$ of current electricity demand due to its large roof area. This is a significant proportion of the electricity generation mix for Malaysia. The large roof areas can help in receiving more solar irradiance thus generating more solar electricity than the urban housing. Since Malay houses have a typical rectilinear form (Yuan, 2010), the collection area for solar energy is more determined by the orientation and inclination of the roofs than their geometry

With roof pitches in Malaysia commonly angled at $45^{\circ}$ or less (Fee et al., 2005; Yuan, 2010) and located near to the equator line, all orientations of the roof have the significant area for solar energy collection. As most rural houses are built on high stilts and located in a large yard, there are minimal issues on overshadowing from trees. With more than 3.5 million rural houses (Department of Statistic Malaysia, 2010), abundant solar energy can be collected from rural roofs, allowing it to be shared widely to other people in the community.

Through rural community, solar village can be created by establishing a community micro-grid, where, the electricity generated from PV panels can be transmitted into the households from the power producer (Frame, Tembo, Dolan, Strachan, \& Ault, 2011). A smart meter can be installed to monitor the electricity consumption. There are many successful international solar co-operative projects that can be followed, for example Westmill Solar Co-operative Project in the UK (Westmill, 2013), SolarShare Co-operative Project in Canada (SolarShare, 2013) and Fukushima Solar Village in Japan (Hsu, 2014). These projects have established community involvement by founding a solar co-operative agency for the rural people. This approach would allow solar energy to be shared by multiple people in the same community (Greenius, 2010). Residents with limited financial capacity or spaces can have access by sharing solar energy facilities with other community members (Iler, 2012) (See Figure 1). This is economical for the people rather than each member of the community investing one whole set of solar panel that is expensive.

With the total cost of solar PV energy being still far beyond the reach for the rural people in Malaysia, it is essential to establish a suitable financing mechanism that can help to spread this technology to all people in rural Malaysia. A case study of a typical village in Malaysia has been conducted to idealistic the solar village concept (See Figure 2). 


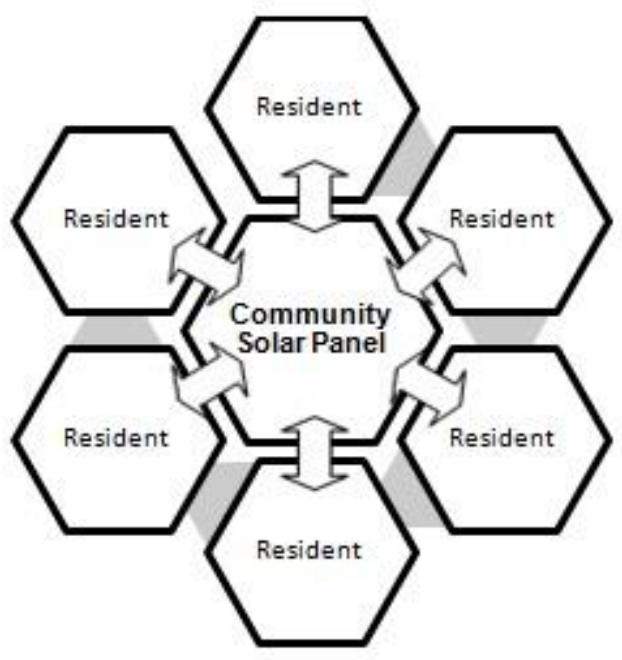

Figure 1. The Concept of Solar Electrification Community (adapted from author's PhD thesis).

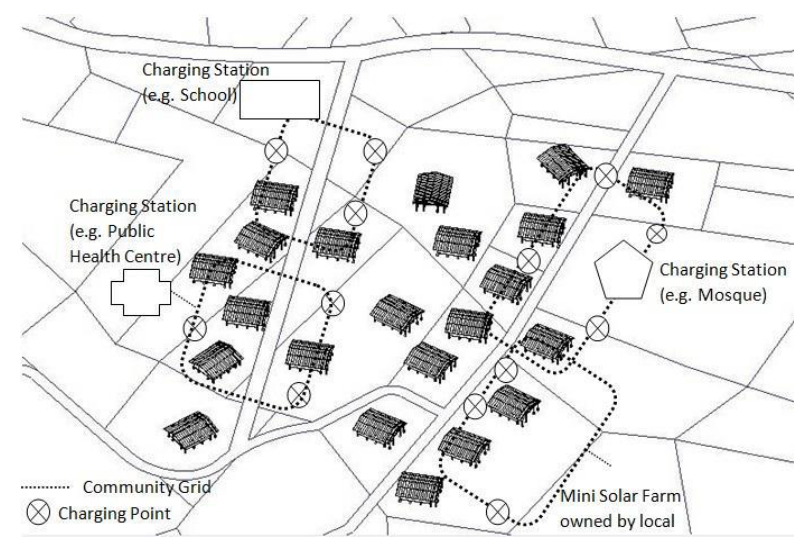

Figure 2. The Concept of Solar Village Community - A Case Study from a Typical Village in Malaysia (adapted from author's $\mathrm{PhD}$ thesis).

Public buildings (for example, mosque, school or public health centre) in the village can operate as a solar charging point which allow nearby dwellers to access solar generated electricity from a community grid (i.e. by paying fees for charging their own battery bank (using the Indian 'fee-for service' concept) (Chaurey \& Kandpal, 2009). This can help rural dwellers with limited financial capacity to access solar generated electricity. Houses with solar PV panels can be installed with smart meters to assess the electricity used and to identify the consumption rate which allows price charging based on the time of day. This is depending on solar incentives scheme provided by the Government. Other houses need to have an inverter charger to connect the battery bank.

\section{The Methodology}

A combination of qualitative and quantitative methods has been conducted based on the aims of this research and has been categorised into the sequence of :-

- Survey research method which contains main questionnaires for rural respondents
- Load profile analysis of rural houses using load meter.

- Supporting questionnaires - In order to gather opinion and measuring trends on electrical appliances of rural households.

- Solar yield analysis for roof' samples.

- Field study - A case study approach to gather data on a load profile of a village.

- Desktop study - An analysis to investigate the potential of rural solar community, together with a numerical analysis on cost feasibility analysis for the investment of a rural solar community.

Figure 3 illustrates the research methodology framework for this study.

\begin{tabular}{|c|c|}
\hline INITIAL STAGE: IDENTIFYING A TOPIC & \\
\hline $\begin{array}{l}\text { - Research Objectives and Research Questions. } \\
\text { - Identifying Gaps, Theories and Perspective. } \\
\text { - The Development of Research Proposal }\end{array}$ & 蛋 \\
\hline $\begin{array}{l}\text { A. DESKTOP STUDY } \\
\text { i. The development of literature reviews } \\
\text { (For Chapter } 2,3 \text { and } 4 \text { ). } \\
\text { ii. Questionnaire design (For Chapter } 6 \text { ). } \\
\text { iii. Sample sizing (Pillot study and main case study). }\end{array}$ & 贾 \\
\hline $\begin{array}{l}\text { B. PILOT STUDY } \\
\text { i. Field Survey (Observation and questionnaires for } \\
40 \text { samples of households) and feld work } \\
\text { (measurement) of the vemacular houses in rural area } \\
\text { (focus : low-income groups in rural Malaysia). } \\
\text { ii. Load profile calculation } \\
\text { iii. Revew and alter the questionnaires based on result } \\
\text { from pilot study. }\end{array}$ & $\begin{array}{l}\text { g } \\
\frac{2}{3} \\
8 \\
0 \\
\end{array}$ \\
\hline $\begin{array}{l}\text { C. CASE STUDY } \\
\text { i. Field Survey (Observations and Questionnaires } \\
\text { (Closed-ended questions) for } 292 \text { households, and } \\
\text { measurement (dimensions) of the households in rural } \\
\text { Malaysia - to compute roof areas. } \\
\text { ii. Case Study (one typical village has been chosen). } \\
\text { iii. Solar yield and load profile assesment. }\end{array}$ & $z$ \\
\hline $\begin{array}{l}\text { D. DESKTOP ANALYSIS } \\
\text { i. Statistical (SPSS) analysis for the questionnaires. } \\
\text { ii. Load profile calculation. } \\
\text { iii. Data evaluation based on case study. } \\
\text { iv. Cost feasibility analysis - using data from the main } \\
\text { case study, to examine capital cost and cost effectiveness } \\
\text { of PV systems in order to identify methods of finance for } \\
\text { low-income people. }\end{array}$ & 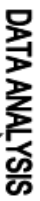 \\
\hline
\end{tabular}

Figure 3. The Research Methodology Framework (adapted from author's $\mathrm{PhD}$ thesis).

\section{The Route Map to Finance a Solar Village}

To establish whether there is adequate electricity produced for the community, a load profile analysis is presented. This analysis assumes that one or more community buildings will have PV systems and a certain proportion of the households in the village. The electricity demand of the whole community is then compared with the electricity generated by PVs. The cost feasibility analysis has been carried out in order to estimate the financial benefit of PV panels installed on rural roofs. Figure 4 shows the proposed route map for financing a solar PV community project for a village. 


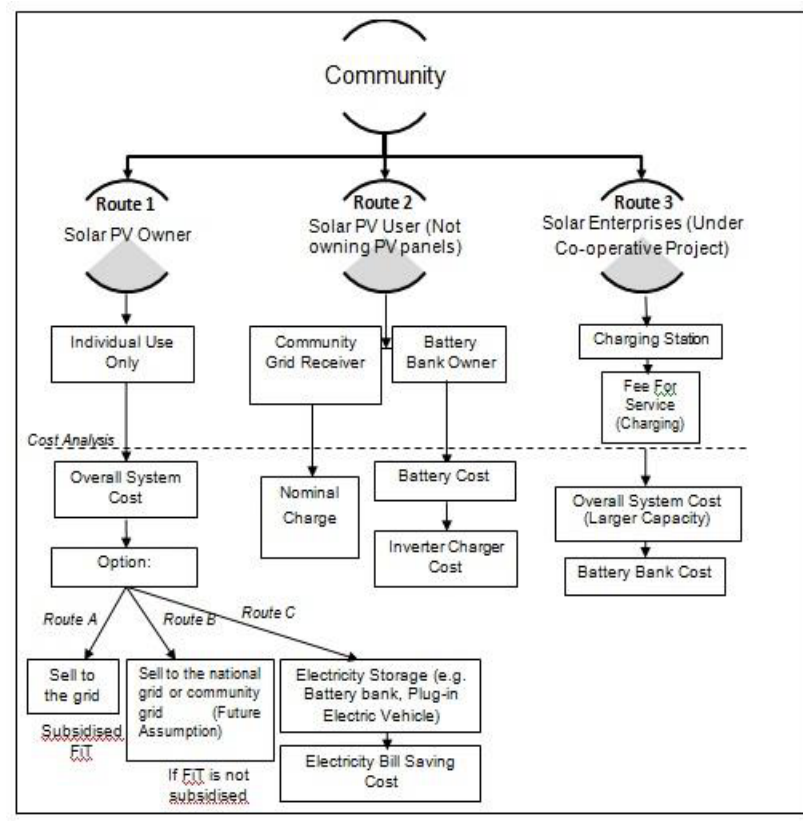

Figure 4. The Route Map for Financing a Solar Village (adapted from author's $\mathrm{PhD}$ thesis).

\subsection{Route 1}

In this study, a $4 \mathrm{kWp}$ PV system has been considered to be used for Route 1 and calculations were based on the pattern of dwellers' occupancy of as follows:-

Category (i) About half leave for work and about half stay.

Category (ii) Most leave for work and one or two stay behind in the day; e.g housewife and children.

Category (iii) Everybody leaves the house in the morning and returns at dusk.

Figure 5 has described the load profile for each category which tabulated the energy used and projected excess energy that can be sold.

In 2011, the overall cost of PV panels for a double storey house is estimated at RM 45,000 (MBIPV, 2011; F. Muhammad-Sukki et al., 2011). After 2013, it is assumed that the installation costs has been minimized to $10 \%$ annually (Ahmad \& Byrd, 2013) making it now between MYR 30,000 to RM 36,000. In addition, the PV system is now locally made in Malaysia (Gading Kencana, 2013) making the cost for the panels cheaper than the imported panels. In order to lower the initial cost, PV panels can be bought by bulk, and village people or local cooperative community can be trained to carry out the installation of the system.

As recommended by Balfour, Shaw, and Nash (2013), lead-acid batteries are suitable for home-PV systems since it is cheaper than the other types of battery. Since home-owners can get the electricity from the grid, they can have an alternate option in using the electricity supply either from the grid or the battery based on their needs (Balfour et al., 2013). Table 1 show the monthly saving rate after PV system is installed based on categories of occupancy.

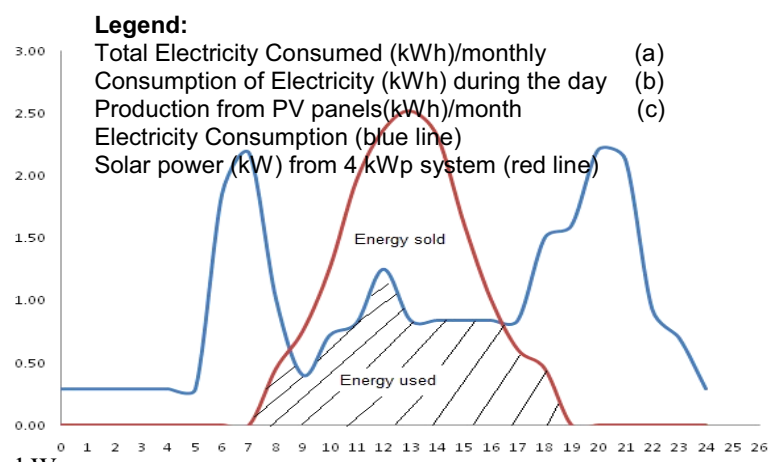

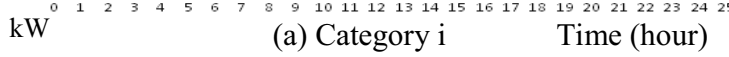
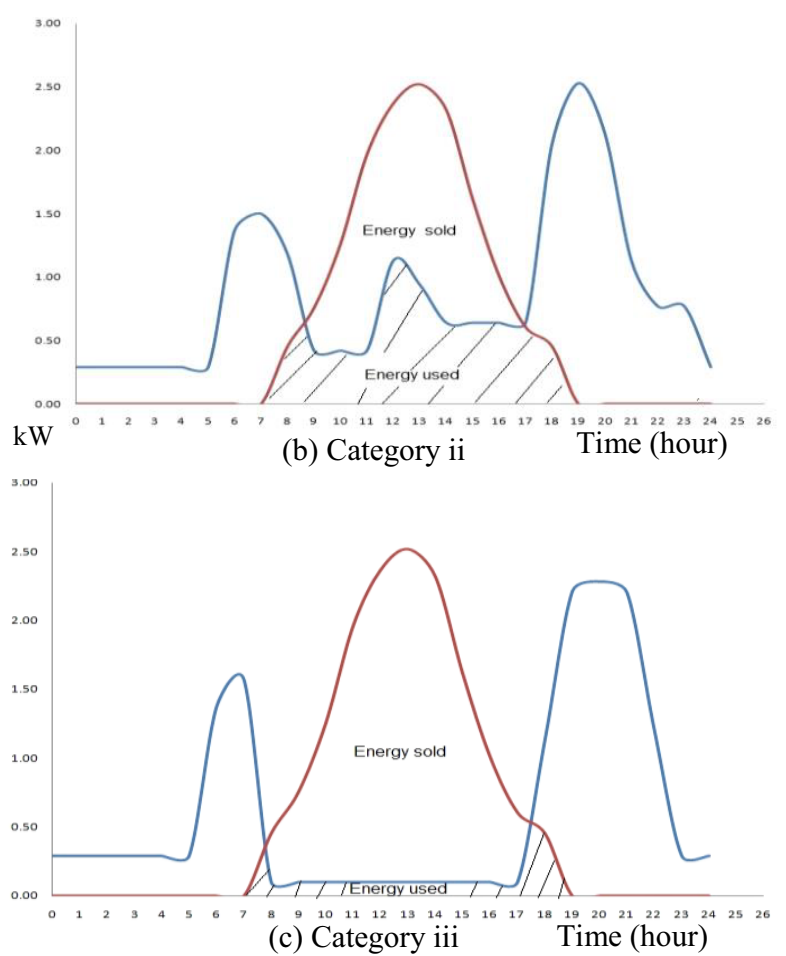

Figure 5(a), (b) and (c). The Load Profile for Every Category of Occupancy

Table 1. Monthly saving rate after PV system is installed in the house.

\begin{tabular}{|c|c|c|c|c|c|}
\hline Category & $\begin{array}{c}\text { Total Electricity } \\
\text { Consumed } \\
(\mathrm{kWh}) \text { monthly } \\
\text { (a) }\end{array}$ & $\begin{array}{l}\text { Consumption } \\
\text { of Electricity } \\
(\mathrm{kWh}) \text { during } \\
\text { the day } \\
\left(\text { b) }{ }^{\circ}\right.\end{array}$ & $\begin{array}{l}\text { Production } \\
\text { from PV } \\
\text { panels } \\
(\mathrm{kWh}) \text { month } \\
(c)^{\circ}\end{array}$ & $\begin{array}{l}\text { Conversion of electricity } \\
\text { saving }(k W h) \text { to financial } \\
\text { saving (MYR) } \\
\text { [b) x.Malaysia's Electricity } \\
\text { tariff 2014 } \\
\text { (MYR)] }\end{array}$ & $\begin{array}{l}\% \text { of } \\
\text { Cost } \\
\text { Saving }\end{array}$ \\
\hline (i) & 420 & 210 & 420 & 46.94 & 34 \\
\hline (ii) & 390 & 105 & 420 & 22.89 & 19 \\
\hline (iii) & 270 & 30 & 420 & 6.54 & 10 \\
\hline
\end{tabular}

* Refer Figure 4

** Based on current Malaysian electricity rate (E.g. For $210 \mathrm{kWh}$ [First 200 units x MYR $0.218=$ MYR 43.60] + [Next 10 units x MYR $0.334=$ MYR 3.34] Total of MYR 46.94)

If the electricity generated from PV is used by the household, the homeowner will only need to pay the electricity bill for the remaining bill which is MYR 46.94, MYR 22.89 and MYR 6.54 respectively with a total cost saving of $34 \%, 19 \%$ and $10 \%$ for each category. Table 2 and 3 has indicated the income that can be gained, if the home owner intends to use and then, sell the surplus of energy from the solar electricity. 
Table 2. Combination use (use and sell) for a $4 \mathrm{kWp} \mathrm{PV}$ system.

\begin{tabular}{|c|c|c|c|}
\hline Category & $\begin{array}{c}\text { Electricity } \\
\text { Produced by PV } \\
\text { Panels } \\
(\mathrm{kWh} / \mathrm{month} \\
(\boldsymbol{a})\end{array}$ & $\begin{array}{c}\text { Consumption } \\
\text { of Electricity } \\
\text { (kWh) during } \\
\text { the } \\
\text { day/monthly } \\
\text { (b) }\end{array}$ & $\begin{array}{c}\text { Surplus } \\
\text { electricity } \\
\text { generated and } \\
\text { sold to the grid } \\
(\mathrm{kWh} / \text { month) } \\
\text { (a) }- \text { (b) }\end{array}$ \\
\hline (i) & 420 & 210 & 210 \\
\hline (ii) & 420 & 105 & 315 \\
\hline (iii) & 420 & 30 & 390 \\
\hline
\end{tabular}

Table 3. Total Income from Feed-in Tariff (FiT) Scheme (For a Combination of Uses).

\begin{tabular}{|c|c|c|c|c|}
\hline Category & $\begin{array}{c}\text { Consumption } \\
\text { of Electricity } \\
\text { (kWh) during } \\
\text { the day } \\
\text { /monthly }\end{array}$ & $\begin{array}{c}\text { Cost of } \\
\text { electricity } \\
\text { (MYR)* } \\
(a)\end{array}$ & $\begin{array}{c}\text { Surplus } \\
\text { electricity } \\
\text { generated } \\
\text { (kWh/ } \\
\text { month) }\end{array}$ & $\begin{array}{c}\text { Income } \\
\text { from } \\
\text { FiT**/ } \\
\text { month } \\
(b)\end{array}$ \\
\hline (i) & 210 & 46.94 & 210 & 266.70 \\
\hline (ii) & 105 & 22.89 & 315 & 400.05 \\
\hline (iii) & 30 & 6.54 & 390 & 495.30 \\
\hline
\end{tabular}

* Based on Malaysia's electricity tariff 2014 (First 200 units: MYR $0.218)$

** Feed-in Tariff (FiT) Rate is MYR 1.27

Rather than selling the surplus of the electricity to the Feed-in Tariff (FiT) ${ }^{\mathrm{b}}$ scheme, the electricity can also be sold to 'peers' using a community grid. Martinot (2014) has introduced a "peer-to-peer" energy model that allows an energy sale among people in a community. Through this scheme, the PV owner can sell their electricity to the neighbours based on nominal charges for the use of local grid (Martinot, 2014). It helps PV owner (supplier) to share or sell electricity directly by 'renting' the cables of the central grid. The 'supplier' must be registered as a 'generator' in order to utilise the central grid cables which are rented from the grid. The supplier (via the grid operator) must meter the electricity exported to the grid and this is compared with the electricity imported by the buyer (see Table 2). At the moment, there is no energy policy in Malaysia that allows the 'supplier' to rent the cables of the central grid to export the generated electricity to the community. Therefore, it is essential for the Government to take this matter into account in order to establish a workable solar village community.

\subsection{Route 2}

${ }^{\mathrm{b}}$ Feed-in Tariff (FiT) is an energy payment scheme established to encourage small-scale energy provider to sell their generated electricity (from small-scale plant; e.g solar panel) to the Government (SEDA, 2012)
Route 2 is for PV user who does not own a PV system, but wants to access the electricity generated from it. They can benefit from the 'peer-to-peer' grid or community grid. For this route, the use of batteries would be essential to benefit the usage during night-time. In this case, they need batteries in order to store electricity collected from the charging point. Table 4 explores the significant calculation for the batteries (based on the categories of occupancy).

Table 4. Analysis on the Battery Bank

\begin{tabular}{|c|c|c|c|c|c|}
\hline Category & $\begin{array}{c}\text { Total } \\
\text { Daily } \\
\text { Use } \\
\text { (Wh/ } \\
\text { day) }\end{array}$ & $\begin{array}{c}\text { Days of } \\
\text { Autonomy } \\
(2 \text { Days })\end{array}$ & $\begin{array}{c}\text { Depth of } \\
\text { Discharge } \\
\text { at } 50 \%\end{array}$ & $\begin{array}{c}\text { Ambient } \\
\text { Temperature } \\
\text { Effect } \\
\left(27^{\circ} \mathrm{C}=\right. \\
\text { Factor } 1)\end{array}$ & $\begin{array}{c}\text { Amp- } \\
\text { hour }(\text { Ah }) \\
\text { Using } \\
\text { formula } \\
(P / V=I)^{*}\end{array}$ \\
\hline (i) & 14000 & $\begin{array}{c}14000 \mathrm{x} \\
2= \\
28000\end{array}$ & $\begin{array}{c}28000 / 0 \\
.5= \\
56000 \mathrm{~W} \\
\mathrm{~h}\end{array}$ & $56000 \times 1$ & $\begin{array}{c}56000 / 48 \\
= \\
1167 \mathrm{Ah}\end{array}$ \\
\hline (ii) & 13000 & $\begin{array}{c}13000 \mathrm{x} \\
2= \\
26000\end{array}$ & $\begin{array}{c}26000 / 0 \\
.5= \\
52000 \mathrm{~W} \\
\mathrm{~h}\end{array}$ & $52000 \times 1$ & $\begin{array}{c}52000 / 48 \\
= \\
1083 \mathrm{Ah}\end{array}$ \\
\hline (iii) & 9000 & $\begin{array}{l}9000 \times 2 \\
=18000\end{array}$ & $\begin{array}{c}18000 / 0 \\
.5= \\
36000 \mathrm{~W} \\
\mathrm{~h}\end{array}$ & $36000 \times 1$ & $\begin{array}{c}36000 / 48 \\
= \\
750 \mathbf{~ A h}\end{array}$ \\
\hline
\end{tabular}

* $\mathrm{P}=$ Power $(\mathrm{Wh}), \mathrm{V}=$ Voltage, $\mathrm{I}=$ Current $(\mathrm{Ah})$, Source: BTEK Energy (2012)

Even though the cost for owning a battery is considered high for low-income people, the amount is invested only in the early stage of usage. The batteries have a typical lifespan of between 10 to 15 years depending on the types and frequency of usage (Balfour et al., 2013). Table 5 has listed the overall cost for battery banks.

Table 5. The Battery Configuration

\begin{tabular}{|c|c|c|c|c|c|}
\hline & $\begin{array}{c}\text { Battery } \\
\text { Capacities } \\
\text { Needed } \\
\text { (Amp- } \\
\text { hour) }\end{array}$ & $\begin{array}{c}\text { Suggestions of } \\
\text { Type of } \\
\text { Battery and } \\
\text { Configurations }\end{array}$ & $\begin{array}{c}\text { Number of } \\
\text { Batteries } \\
\text { Needed }\end{array}$ & $\begin{array}{c}\text { Price } \\
\text { Per } \\
\text { Unit } \\
\text { (MYR)* }\end{array}$ & $\begin{array}{c}\text { Total } \\
\text { Cost } \\
\text { (MYR) }\end{array}$ \\
\hline (i) & 1167 & $\begin{array}{c}48 \mathrm{~V}, 600 \mathrm{Ah} \\
\text { (Lead-Acid) } \\
\text { Parallel } \\
\text { Arrangement }\end{array}$ & 2 & $4,750.00$ & $9,500.00$ \\
(ii) & 1083 & $\begin{array}{c}12 \mathrm{~V}, 546 \mathrm{Ah} \\
\text { (Lead-Acid) } \\
\text { Series and } \\
\text { Parallel } \\
\text { Arrangement }\end{array}$ & 4 & $2,300.00$ & $9,200.00$ \\
\hline & 750 & $\begin{array}{c}12 \mathrm{~V}, 400 \mathrm{Ah} \\
\text { (Lead-Acid) } \\
\text { Series and } \\
\text { Parallel } \\
\text { Arrangement }\end{array}$ & 4 & $1,700.00$ & $6,800.00$ \\
\hline
\end{tabular}

* Based on various supplier price in Malaysia

\subsection{Route 3}

Route 3 is used to establish a solar enterprise that can be utilised by people in the village, micro-enterprises or cooperative agencies who own PV systems. The main characteristic of this route is to provide a community grid with a charging station that can be linked with battery banks. Brumback (2013) has argued that the solar enterprise can act as a charging station by using public buildings in the area, for example a school, or people who whom owns land that can be incorporated into a mini solar farm. By arranging a certain charging fee, local 
people can charge their battery banks from these charging points. Many international project has been using this concept, for instance, a public street charger in New York (Street Charge, 2013), solar lantern project in India (Chaurey \& Kandpal, 2009), solar micro-enterprises in Bangladesh (Barua, 2001) and several micro grid projects in remote Kenya (PowerGen, 2014).

By referring to Figure 2, the existing electric pole can be used to locate charging points and can be rented from the main utility. The charging station would be community owned and since public buildings are reasonably centrally located, they would set up charging points within a radius. It would be better if the power distributed was in Alternating Current (AC) circuit, in order to save the cost of inverters, to reduce distribution losses and to be useful for electric vehicle charging. The charging fees can be setup by establishing an agreement between the generator (solar enterprise) and the receiver (the households and other users) - the same concept applies in Route 1 . The price of electricity can be determined by the community.

Since the price of the system is typically 16 times beyond the financial capability of rural households (see Table 6), it is essential to consider the financing mechanism that can help them. There are a few financing schemes that can be integrated into financing a PV systems (Refer Figure 6 and Table 7).

Table 6. Indicative Cost for Setting up a Charging Station For a Solar Village

\begin{tabular}{|c|c|}
\hline System & Cost (MYR) \\
\hline $\begin{array}{c}\text { System cost (20kWp)** - inclusive } \\
\text { with inverter/charger and } \\
\text { installation cost* }\end{array}$ & $64,000.00$ \\
\hline Battery bank* & $40,000.00$ \\
\hline Cables and Charging Point* & $50,000.00$ \\
\hline Overall Cost (MYR) & $154,000.00$ \\
\hline
\end{tabular}

*Price from Gading Kencana (2013)

**For this analysis, $20 \mathrm{kWp} \mathrm{PV} \mathrm{system} \mathrm{is} \mathrm{used;} \mathrm{which}$ significant with larger roof area (mosque, school, etc)

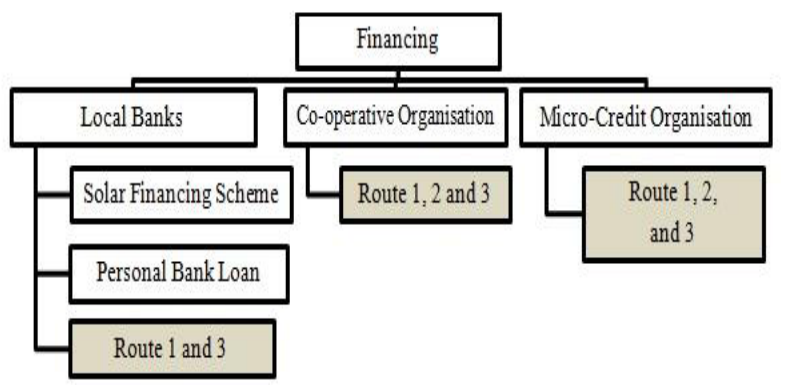

Figure 6. Types of Financing Mechanism.
Table 7. The Characteristics of Each Financing Mechanism

\begin{tabular}{|c|c|c|c|}
\hline & Bank & $\begin{array}{c}\text { Cooperative } \\
\text { Organisation }\end{array}$ & $\begin{array}{c}\text { Micro-Credit } \\
\text { Organisation }\end{array}$ \\
\hline $\begin{array}{c}\text { Interest } \\
\text { Rate (\%) }\end{array}$ & $6.35 \%$ & $2.5 \%$ & $1.9 \%$ \\
\hline $\begin{array}{c}\text { Fixed or } \\
\text { Variable }\end{array}$ & Variable & Fixed & Fixed \\
\hline $\begin{array}{c}\text { Maximu } \\
\mathrm{m} \\
\text { Financing } \\
\text { (MYR) }\end{array}$ & Negotiable & 100,000 & 50,000 \\
\hline $\begin{array}{c}\text { Tenure } \\
\text { Terms } \\
\text { (Year) }\end{array}$ & 10 & 10 & 5 \\
\hline Remarks & & $\begin{array}{l}\text { Interest rate is } \\
\text { between } 1 \% \text { - } \\
4 \% \text { Average } \\
\text { interest is } \\
\text { considered. }\end{array}$ & \\
\hline
\end{tabular}

All routes can benefit from cooperative or microcredit organizations financing, depending on the suitability of the applicants. The drawback of financing from bank is the requirements for eligible applicants, which only opens to households with monthly income of MYR 3,000 and above, and within the range of age between 21 - 55 years (Alliance Bank, 2013; Gading Kencana, 2013). Most of rural households have income below that MYR 1500 and average age is between 50-70 years old (Department of Statistic Malaysia, 2011). The return of investment (ROI) for each types of financing is shown in Table 8 . All the proposed routes have a payback period of between three to twelve years. This length of time is considered normal and acceptable the country ${ }^{\mathrm{c}}$.

\section{Conclusion}

The advantages of community owned buildings being fitted with larger PV systems with a large roof can generate larger amounts of electricity and with the larger battery storage, it allows for a solar village to be set up on the basis of charging points in the immediate local vicinity. Loans from cooperative organisations are more attractive but micro-credit organisations are the most financially attractive. All the proposed routes have a payback period of between three to twelve years. The analysis indicates that the Feed-in Tariff (FiT) has some initial benefits for PV owners but the principal drawback is that any surplus electricity generated is unlikely to be fed directly into the grid and hinder the way to the establishment of solar village.

\footnotetext{
${ }^{\mathrm{c}}$ For example, loans on cars are frequently taken out on a seven, eight or nine year period.
} 
Table 8. The Payback Period

\begin{tabular}{|c|c|c|c|c|c|c|c|c|c|c|c|c|c|c|c|}
\hline \multirow[b]{2}{*}{ Year } & \multirow[b]{2}{*}{$\begin{array}{r}\text { Route } \\
\text { A }\end{array}$} & \multicolumn{4}{|c|}{ Capital Cost (MYR) } & \multirow[b]{2}{*}{$\begin{array}{c}\text { Net } \\
\text { Benefit } \\
\text { (MYR) }\end{array}$} & \multicolumn{9}{|c|}{ Financing (Annual Payment with Interest) } \\
\hline & & $\begin{array}{c}\text { PV } \\
\text { System }\end{array}$ & $\begin{array}{c}\text { Battery } \\
\text { Bank }\end{array}$ & $\begin{array}{c}\text { Other } \\
\text { (Community } \\
\text { Grid, Cable, } \\
\text { Mischellanous) }\end{array}$ & \begin{tabular}{|c|}
$\begin{array}{c}\text { Total } \\
\text { (MYR) }\end{array}$ \\
B \\
\end{tabular} & & $\begin{array}{c}\text { Bank (C) } \\
6.35 \%= \\
\text { Annual } \\
\text { Capital } \\
\text { (MYR 2700) }\end{array}$ & $\begin{array}{c}\text { Cumulative } \\
\text { Amount } \\
\text { (MYR) }\end{array}$ & $\begin{array}{l}\text { Payback } \\
\text { Period }\end{array}$ & $\begin{array}{c}\text { Cooperative (D) } \\
2.50 \%=\text { Annual } \\
\text { Capital } \\
\text { (MYR 2700) }\end{array}$ & $\begin{array}{c}\text { Cumulative } \\
\text { Amount } \\
\text { (MYR) }\end{array}$ & $\begin{array}{c}\text { Payback } \\
\text { Period }\end{array}$ & $\begin{array}{c}\text { Micro- } \\
\text { Organisation (E) } \\
1.90 \%=\text { Annual } \\
\text { Capital } \\
\text { (MYR 5400) }\end{array}$ & $\begin{array}{c}\text { Cumulative } \\
\text { Amount } \\
\text { (MYR) }\end{array}$ & $\begin{array}{c}\text { Payback } \\
\text { Period }\end{array}$ \\
\hline 1 & \multirow{10}{*}{ Route 1} & \multirow{10}{*}{16000} & \multirow{10}{*}{11000} & \multirow{10}{*}{0.0} & \multirow{10}{*}{27000} & 4026.00 & 1714.50 & 28714.50 & \multirow{6}{*}{5} & 27675.00 & 27675 & \multirow{5}{*}{4} & 513.00 & \begin{tabular}{|l|l|} 
& 27513.00 \\
\end{tabular} & \multirow{3}{*}{3} \\
\hline 2 & & & & & & 4571.97 & 1396.27 & 23384.77 & & 21472.73 & 21472.73 & & 343.65 & 18430.65 & \\
\hline 3 & & & & & & 4465.16 & 1023.16 & 17135.97 & & 14555.78 & 14555.78 & & 160.72 & 8619.40 & \\
\hline 4 & & & & & & 4347.60 & 633.15 & 10603.96 & & 7211.49 & 7211.49 & & & & \\
\hline 5 & & & & & & 4218.95 & 225.83 & 3782.19 & & & & & & & \\
\hline 6 & & & & & & 4078.86 & & & & & & & & & \\
\hline 7 & & & & & & 3926.99 & & & & & & & & & \\
\hline 8 & & & & & & 3762.95 & & & & & & & & & \\
\hline 9 & & & & & & 3586.39 & & & & & & & & & \\
\hline 10 & & & & & & 3396.91 & & & & & & & & & \\
\hline 1 & & & & & & 1159.50 & & & & & & & 209.00 & 11209.00 & \\
\hline 2 & & & & & & 1374.59 & & & & & & & 149.14 & 7998.64 & 4 \\
\hline 3 & Route 2 & 0 & 11000 & 0.0 & 11000 & 1509.58 & & & & & & & 84.06 & 4508.11 & 4 \\
\hline 4 & & & & & & 1644.77 & & & & & & & 15.17 & 813.70 & \\
\hline 5 & & & & & & 1780.17 & & & & & & & & & \\
\hline 1 & & & & & & 4026.00 & 10033.00 & 168033.00 & & 3950.00 & 161950.00 & & 3002.00 & 161002.00 & \\
\hline 2 & & & & & & 4571.97 & 9411.14 & 157618.14 & & 4121.60 & 146245.60 & & 2382.14 & 127758.14 & \\
\hline 3 & & & & & & 4465.16 & 8715.13 & 145961.31 & & 3530.81 & 125282.84 & & 1694.88 & 90898.91 & 5 \\
\hline 4 & & & & & & 4347.60 & 7981.71 & 133677.86 & & 2943.12 & 104430.00 & & 1009.64 & 54148.52 & \\
\hline 5 & & & & & & 4218.95 & 7209.17 & \begin{tabular}{|l|}
120739.44 \\
\end{tabular} & & 2358.84 & 83698.12 & 9 & 326.63 & 17517.92 & \\
\hline 6 & & & & & & 4078.86 & 6395.75 & 107116.24 & 12 & 1778.29 & 63098.63 & & & & \\
\hline 7 & Route 3 & 64000 & $\mid 44000$ & 50000.0 & 158000 & 3926.99 & 5539.57 & 92776.95 & 12 & 1201.80 & 42643.28 & & & & \\
\hline 8 & & & & & & 3762.95 & 4638.67 & 77688.64 & & 629.72 & 22344.21 & & & & \\
\hline 9 & & & & & & 3586.39 & 3690.98 & 61816.67 & & 62.39 & 2213.93 & & & & \\
\hline 10 & & & & & & 3396.91 & 2694.32 & 45124.60 & & & & & & & \\
\hline 11 & & & & & & 2998.36 & 1646.41 & 27574.102 & & & & & & & \\
\hline 12 & & & & & & 3143.32 & 557.26 & 9333.005 & & & & & & & \\
\hline
\end{tabular}

\section{References}

1. Ab Kadir, M. Z. A., Rafeeu, Y., \& Adam, N. M. (2010). Prospective scenarios for the full solar energy development in Malaysia. Renewable and Sustainable Energy Reviews, 14(9), 3023-3031. doi: DOI: 10.1016/j.rser.2010.07.062

2. Ahmad, N. A., \& Byrd, H. (2012). Photovoltaics in Malaysia: Challenges and Strategies Towards Resilient Rural Areas in Malaysia. Paper presented at the International Malaysia-Auckland Research Conference (iMARCA 2012), Auckland.

3. Ahmad, N. A., \& Byrd, H. (2013). Empowering Distributed Solar PV Energy For Malaysian Rural Housing: Towards Energy Security And Equitability Of Rural Communities. International Journal of Renewable Energy Development (IJRED), 2(1), 5968.

4. Alliance Bank. (2013). Home Complete Plus - Solar Panel Financing, 2013, from http://www.alliancebank.com.my/Personal-

Banking/Loans/Home-Loans/Home-Complete-PlusSolar-Panel-Financing.aspx

5. APEC. (2006). Energy Demand and Supply Outlook 2006 (pp. 49-53): Asia Pacific Energy Research Centre

6. APEC. (2013). Energy Demand and Supply Outlook (5th ed., pp. 97-108): Asia Pacific Energy Research Centre
7. Balfour, J., Shaw, M., \& Nash, N. B. (2013). Advanced Photovoltaic System Design. Burlington: Jones \& Bartlett Learning.

8. Barnes, D. (2005). Meeting the Challenge of Rural Electrification in Developing Nations: The Experience of Successful Programs (March 2005 ed., pp. 362). US: Energy Sector Management Assistance Program (ESMAP).

9. Barnes, D., \& Foley, G. (2004). Rural Electrification In The Developing World: A Summary Of Lessons From Successful Programs (December ed.). Washington: Joint UNDP/World Bank Energy Sector Management Assistance Programme (ESMAP).

10. Barua, D. C. (2001). Strategy for promotions and development of renewable technologies in Bangladesh: experience from Grameen Shakti. Renewable Energy, 22(1-3), 205-210. doi: 10.1016/s0960-1481(00)00012-4

11. Brumback, E. (2013, 28 April 2013). Utility co-op offers community-based approach to access solar energy, MiBiz. Retrieved from http://mibiz.com/news/energy/item/20599-utility-coop-offers-community-based-approach-to-accesssolar-energy

12. BTEK Energy. (2012). How to Size a Battery Bank Retrieved $21 \quad$ Feb 2014, from http://www.btekenergy.com/documents/215.html

13. Byrd, H. (2010). The Potential of PVs In Developing Countries: Maintaining An Equitable Society In The 
Face Of Fossil Fuel Depletion. Paper presented at the International Conference on Environment 2010, Penang.

14. Chaurey, A., \& Kandpal, T. C. (2009). Solar lanterns for domestic lighting in India: Viability of central charging station model. Energy Policy, 37(11), 49104918. doi: http://dx.doi.org/10.1016/j.enpol.2009.06.047

15. Chua, S. C., Oh, T. H., \& Goh, W. W. (2011). Feedin tariff outlook in Malaysia. Renewable and Sustainable Energy Reviews, 15(1), 705-712. doi: DOI: 10.1016/j.rser.2010.09.009

16. Department of Statistic Malaysia. (2010). Preliminary Count Report. Putrajaya: Government of Malaysia

17. Department of Statistic Malaysia. (2011). Taburan Penduduk dan Ciri-Ciri Asas Demografi (T. D. o. S. Malaysia, Trans.) Census 2010 (pp. 5). Kuala Lumpur.

18. EIA. (2013). Short Term Energy Outlook (March 2013 ed.). Washington: EIA.

19. Fantazzini, D., Höök, M., \& Angelantoni, A. (2011). Global oil risks in the early 21 st century. Energy Policy, 39(12), 7865-7873. doi: 10.1016/j.enpol.2011.09.035

20. Fee, C. V., Sani, A., Nidzam, A., Barlow, H. S., Michael, J., Gurupiah, \& Hashim, D. M. (2005). The Encyclopedia of Malaysia, Volume 5 : Architecture (Vol. 5). Kuala Lumpur: Archipelogo Press,.

21. Frame, D., Tembo, K., Dolan, M. J., Strachan, S. M., \& Ault, G. W. (2011, 24-29 July 2011). A community based approach for sustainable off-grid PV systems in developing countries. Paper presented at the Power and Energy Society General Meeting, 2011 IEEE.

22. Gading Kencana. (2013). Sun2Cash. In SEDA (Ed.), (pp. 4). Kuala Lumpur: Gading Kencana.

23. Gardner-Stephens, R. (2013). TNB to Review Malaysia Electricity Tariff. Power Insider Asia.

24. Hamid, K. A., \& Rashid, Z. A. (2012). Chapter 9: Economic Impacts of Subsidy Rationalization Malaysia. In Y. Wu, X. Shi \& F. Kimura. (Eds.), Energy Market Integration in East Asia: Theories, Electricity Sector and Subsidies (ERIA Research Project Report 2011-17 ed., pp. 207-252). Jakarta: ERIA.

25. Haw, L. C., Sopian, K., Sulaiman, Y., Hafidz, M., \& Yahya, M. (2009). Assessment of Public Perception on Photovoltaic Application in Malaysia Urban Residential Areas Using Trudgill's Framework for Analysis. European Journal of Social Sciences, Vol 8(Number 4), 589-603. doi: 10.2202/19416008.1093

26. Hsu, J. (2014). Japan Plants Renewable Energy Village in Fukushima's Contaminated Farmland, 2016, from http://spectrum.ieee.org/tech-talk/greentech/solar/japan-plants-renewable-energy-village-infukushimas-contaminated-farmland

27. IEA. (2013). Energy Security Retrieved 8/4/2013, from http://www.iea.org/topics/energysecurity/

28. Islam, A. K. M. S., \& Islam, M. (2005). Status of Renewable Energy Technologies in Bangladesh.
ISESCO Science and Technology Vision, Vol 1(May 2005), 51-60.

29. Malaysia. (2006). 9th Malaysia Plan (2006-2010). Kuala Lumpur: The Government of Malaysia.

30. Martinot, E. (2014). No Rooftop Left Behind. Solar Journal.

31. MBIPV. (2011). PV System Cost, from http://www.mbipv.net.my/content.asp?zoneid=4\&cat egoryid $=12$

32. Mekhilef, S., Safari, A., Mustaffa, W. E. S., Saidur, R., Omar, R., \& Younis, M. A. A. (2011). Solar energy in Malaysia: Current state and prospects. [doi: 10.1016/j.rser.2011.08.003]. Renewable and Sustainable Energy Reviews(0).

33. Muhammad-Sukki, F., Ramirez-Iniguez, R., AbuBakar, S. H., McMeekin, S., \& Stewart, B. (2011). An evaluation of the installation of solar photovoltaic in residential houses in Malaysia: Past, present, and future. [doi: 10.1016/j.enpol.2011.09.052]. Energy Policy, 39(12), 7975-7987.

34. Muhammad-Sukki, F., Ramirez-Iniguez, R., AbuBakar, S. H., McMeekin, S. G., Stewart, B. G., \& Chilukuri, M. V. (2011, 6-7 June 2011). Feed-In Tariff for solar PV in Malaysia: Financial analysis and public perspective. Paper presented at the Power Engineering and Optimization Conference (PEOCO), 20115 th International.

35. Nel, W. P., \& Cooper, C. J. (2009). Implications of fossil fuel constraints on economic growth and global warming. Energy Policy, 37(1), 166-180. doi: 10.1016/j.enpol.2008.08.013

36. Pellegrini, L., \& Tasciotti, L. (2012). Rural Electrification Now and Then: Comparing Contemporary Challenges in Developing Countries to the USA's Experience in Retrospect. Forum for Development Studies, 1-24.

37. PEMANDU. (2011). Government Transformation Program. Kuala Lumpur: : Government of Malaysia.

38. PowerGen. (2014). Micro Grids Retrieved 17/7/2014, from http://powergen-renewableenergy.com/micro-grids/

39. Saidur, R., Masjuki, H. H., \& Jamaluddin, M. Y. (2007). An application of energy and exergy analysis in residential sector of Malaysia. Energy Policy, 35(2), 1050-1063. doi: http://dx.doi.org/10.1016/j.enpol.2006.02.006

40. SEDA. (2012). FiT Rates for solar PV, from http://seda.gov.my/

41. Shagar, L. (2013). Electricity tariff up by average $15 \%$ from Jan 1, The Star. Retrieved from http://www.thestar.com.my/News/Nation/2013/12/02 /Electricity-tariff-increase-Jan-1-2014/

42. SolarShare. (2013). Invest in a Brighter Future Retrieved 19 Feb 2014, 2014, from http://www.solarbonds.ca/

43. Street Charge. (2013). Street Charge, 2014, from http://street-charge.com/

44. Subhes, B. C. (2006). Energy access problem of the poor in India: Is rural electrification a remedy? [doi: 10.1016/j.enpol.2005.08.026]. Energy Policy, 34(18), 3387-3397. 
45. The World Bank. (2013). GDP growth (annual \%). Retrieved 31 Aug 2013, from The World Bank Group

http://data.worldbank.org/indicator/NY.GDP.MKTP. KD.ZG

46. TNB. (2009). Powering The Nation (1949 - 2009) (T. N. B. (TNB), Trans.) (Vol. 1, pp. 313). Malaysia: Tenaga Nasional Berhad.

47. Westmill. (2013). Westmill Solar Coop Retrieved 19 Feb 2014, 2014, from http://www.westmillsolar.coop/

48. Yuan, L. J. (2010). The Malay House: Principles to Building Simple and Beautiful Homes for Comfort and Community. Kuala Lumpur: Fox Chapel Publishing 